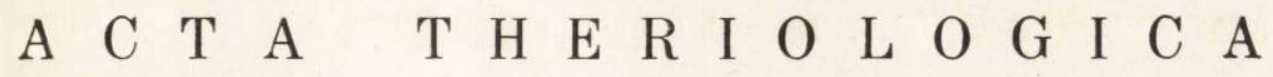

VOL. 20, 26: $333-341$.

August, 1975

Hanna GR U N W L D ${ }^{1}$

\section{Changes in Trappability of Common Vole ${ }^{2}$}

\author{
[With 1 Table \& 2 Figs.]
}

\begin{abstract}
Individuals of Microtus arvalis (P a lla s, 1779) were trapped by the CMR method on a 1 ha plot of alfalfa culture. The trappability of individuals in the whole population, as well as separately for both sexes and in particular age groups was calculated from the ratio of actual to all possible trappings. It was found that $M$. arvalis shows a low trappability. The dynamics of trappability in the investigated population was affected by changes in the activity of individuals depending on phenological factors and occurrence of the breeding season. During the latter period some differences in the trappability of males and females were observed. On the other hand, no changes were found in the trappability of individuals in relation to age.
\end{abstract}

\section{INTRODUCTION}

The estimations of real trappability can be only obtained by methods based on multiple trappings of labelled individuals (Catch-Mark-Release). The animals are captured into various types of live traps that are arrangeed in a different manner on the study area and employed in a variable number. The period of their availability to the animals varies in particular studies. All these factors cause that the obtained values of trappability may differ considerably depending on the employed method (A nd r zejewski \& Wrocławek, 1963; Kikkawa, 1964; Andrzejewski et al., 1966; Ryszkowski, Andrzejewski \& Petrusew i c z, 1966).

Changes in the trappability of individuals observed within one definite method of investigations are caused by alterations of biocenotic and population factors affecting the reaction of individuals to traps ( $\mathrm{K} \mathrm{i} \mathrm{k} \mathrm{k} \mathrm{a} \mathrm{w} \mathrm{a,}$

\footnotetext{
1 Present address: ul. Marsylska $3 \mathrm{~m}$. 85, 02-763 Warszawa

2 Praca została zrealizowana w ramach problemu węzłowego 09.1.7., koordynowanego przez Instytut Ekologii PAN.
} 
1964). The analysis of these changes enables drawing conclusions on the ecological situation of a given population.

Different trappability of particular individuals and some groups arbitrarily distinguished in respect of age, sex, body weight and other ecological parameters results among others from their different position in social hierarchy. Thus when comparing the trappability of individuals or groups it is possible to draw some conclusions on social conditions occurring in a given population (Andrzejewski, Petrusewicz \& Walkowa,'1959; Andrzejewski, Petrusewicz \& Waszki ewicz-Gliwicz, 1967).

The trappability of Microtus arvalis (Pallas, 1779) has not been hitherto investigated hence this study was aimed at the description of dynamics of trappability of this species and at analysis of changes in the trappability of individuals that differ in age, sex and body weight.

\section{MATERIAL AND METHOD}

The investigations of the population of common vole were carried out on a 1 ha experimental plot of alfalfa in Łomna near Warsaw. The plot was surrounded by an eternite fence $0.6 \mathrm{~m}$ high and dug into the ground to the depth of $0.6 \mathrm{~m}$. Such fence protected the plot both from escape of examined individuals and from migration of new voles from the neighbouring fields. All the individuals subjected to the analysis of trappability were born after building the fence. The data on their trappability were collected by the CMR method. Standard live-traps constructed in the Institute of Ecology of Polish Academy of Sciences (O lszewski, 1968) were used. They were set in groups of three in each trapping point near the vole colony. The bait consisted of oats.

The trappings were carried out for two days in each week and included four 12-hour exposures of traps (two daily and two nightly). Hence each rodent could be trapped four times in a week.

During the inspection of traps the following data concerning the individuals were registered: identification number, sex, body weight, date of trapping. The data were then analyzed according to the "calendar of trappings" (Petrusewicz \& Andrzejewski 1962; Andrzejewski, 1969) and they allowed to calculate the real trappability of the examined population and appropriate groups distinguished in respect of age, body weight and sex in consecutive weekly series of trappings.

The real trappability of an individual or of a group corresponds to the ratio of number of trappings during the experiment to the total number of trappings which could occur for this individual or for the group (Petrusewicz \& Andr zejew ski, 1962; Andrzejewski, 1969). The trappability is expressed by the formula: $P=C:(a \times N)$, where:

$C$ - number of trappings obtained for all the individuals of the population, or individuals belonging to particular groups,

$N$ - number of individuals of the population or particular groups staying during the experiment on the plot,

a - number of exposures of traps.

The number of exposures was constant in all series of trappings except a few 
summer series, when it was reduced on account of hot weather causing significant mortality of captured individuals in the traps. In series 36 (July 1971) and 37 (August 1971) only two night exposures were carried out, while in series 39 and 40 (August 1971) and in 78 and 81 (June 1972) - three exposures were completed (two at night and one during the day).

From the trappability reached by the whole population and by individuals in particular groups in consecutive weekly trappings the weighted mean was computed for the period of one month. The series consisting of less than 6 individuals (when computing the mean trappability of individuals in the whole population) or less than 3 (when computing the mean trappability of individuals in particular weight classes) were not taken into consideration during calculation of the mean.

The present study constitutes a part of broad investigations carried cut by the Institute of Ecology of Polish Academy of Sciences on the population of Microtus arvalis. The materials concerning trappability were collected during these investigations from November 1970 till June 1972. Altogether 12,908 trappings were obtained including 1,555 individuals during 316 exposures of traps.

\section{RESULTS}

\subsection{Trappability and Age of Individuals}

In order to analyze the changes in trappability of individuals depending on age some suitable groups were selected. The individuals trapped for the first time in the same month were regarded as belonging to one age class. In such way 12 one-month groups were selected (XI and XII 1970 and I-XI 1971). They included individuals trapped for the first time in the period from November 1970 till November 1971. The investigations did not include individuals trapped for the first time in November 1971. The studies were continued till June 1972 but they concerned only the individuals from already selected groups, and were ended in the moment when these individuals were not trapped any more. The population includer also individuals that appeared before November 1970. Their first trappings occurred during a few preceding months, but they were treated as one group numbered »zero".

In effect of the analysis it was found that the trappability of individuals, which were captured for the first time in February, August, October and November 1971, and individuals captured for the first time before November 1970 shows a general trend to increase with age. This trend, however, is not so clear to be regarded as a rule, the more so that the trappability of individuals captured for the first time in November 1970, April and July 1971 decreased with age, and those trapped for the first time in May, June and September 1971 changed without any regularity. Thus it appears that in the population of $M$. arvalis no definite changes in the trappability take place in relation to the age of individuals. The values of trappability of individuals in definite groups were in 
principle similar in the same months of the year (Fig.1). Deviations occurred among males of the May group in July, and in November group (from 1971) in March, as well as among females from group 0 in the period from May to July, in November group (from 1970) in January, and April group in April and July. Perhaps they can be explained by a low numbers in groups in these months. Changes in the trappability of

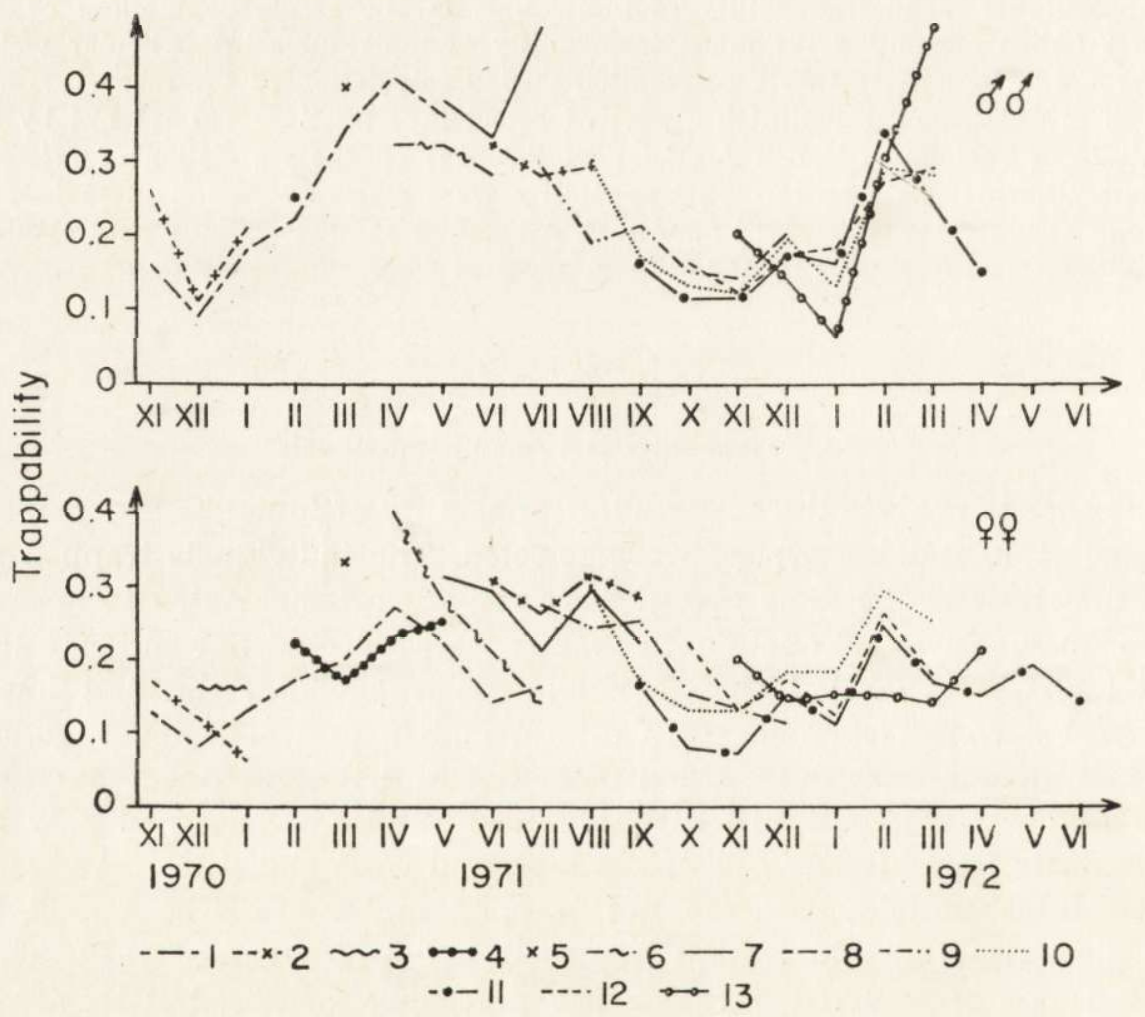

Fig. 1. Changes of trappability of individuals in particular age groups.

1 - group of individuals trapped for the first time before November 1970, 2 group of individuals trapped for the first time in November $1970,3-$ in December 1970, 4 - in February 1971, 5- in March 1971, 6 - in April, 7 - in May, 8 - in June, 9 - in July, 10 - in August, 11 - in September, 12 - in October, 13 in November 1971.

individuals in the remaining groups occurred in a synchronous manner showing cyclic variability during the year. In the period from November 1970 till November 1971 the highest values of trappability were observed among individuals in spring and summer, while the lowest in winter. In the period from November 1971 till June 1972 not the whole population was investigated but only its oldest part, hence changes in the 
trappability occurred in a slightly different manner. After an initial increase from November to the maximum in February the trappability decreased quickly. The character of these changes was similar to those observed in group 0 , including the oldest part of the population in the previous year.

\subsection{Changes in the Trappability of Males and Females}

In the described investigations males reached a higher trappability than females, the differences being particularly distinct in the periods of high trappability, and decreased at low trappability (Fig. 2).

In the spring-summer period 1971 the trappability of males rised quickly till April to reach the maximum of 0.39 , and then gradually decreased. Females reached the maximum trappability of 0.28 in April, and a similar level persisted till August. From that moment the trappability of individuals of both sexes decreased in a similar manner.



Fig. 2. Changes in trappability of the population of $M$. arvalis.

The maximum difference in the trappability of males and females observed in March amounted to $1 / 3$ of the maximum trappability of males.

Despite these differences changes in the trappability of individuals showed a similar course in the year cycle in both sexes. Hence it appears that seasonal changes in the trappability are more prononunced than those depending on sex.

\subsection{Trappability and Body Weight of Individuals}

In order to carry out the analysis of relationship between trappability and body weight of individuals the age classes were further divided into subclasses differing by $10 \mathrm{~g}$ in body weight. The first class included individuals weighing up to $10 \mathrm{~g}$, second - between 11 and $20 \mathrm{~g}$, third 
21 to $30 \mathrm{~g}$, and fourth -31 and $40 \mathrm{~g}$. When dividing females into sutclasses no attention was paid to the stage of the reproduction cycle (pregnant, lactating and sexually immature females were treated jointly).

Individuals belonging to the first weight class (up to $10 \mathrm{~g}$ ) occurred in few age groups only, probably due to the fact that being the youngest they just reached the trapping age required for the active capture into the trap (Gliwicz, 1970).

Individuals belonging to the next two classes, showing body weight in the range of $11-20 \mathrm{~g}$ and $21-30 \mathrm{~g}$, occurred in all age groups. The heaviest individuals, weighing 31 to $40 \mathrm{~g}$, occurred in those groups, in which the first individuals were trapped in April, May, June and July 1971, and before November 1970, both among males and females. Among males they appeared in February 1971 and occurred till August, while

Table 1

The values of correlation coefficients $(r)$ between the total trappability of age groups and trappability of weight classes.

\begin{tabular}{lcccccc}
\hline \multirow{2}{*}{$\begin{array}{l}\text { Weight } \\
\text { class }\end{array}$} & \multicolumn{2}{c}{ Males } & & \multicolumn{2}{c}{ Females } \\
\cline { 2 - 3 } \cline { 5 - 6 } & $r$ & No. samples & & $r$ & No. samples \\
\hline $11-20$ & 0.86 & 49 & & 0.73 & 51 \\
$21-30$ & 0.45 & 44 & & 0.78 & 35 \\
$31-40$ & $-0.30^{1}$ & 13 & & 0.60 & 20 \\
\hline
\end{tabular}

1 Correlation statistically not significant.

among females they were found between April and September. The period of occurrence of these individuals in the population coincides with the period of high trappability (Table 1).

\section{DISCUSSION}

The described investigations indicate that $M$. arvalis shows a low trend for trapping. The mean trappability of individuals in the examined population amounted to 0.20 , while the corresponding value for Clethrionomys glareolus ( $\mathrm{S} \mathrm{chreber}, 1780$ ) in the investigations carried out in a similar manner was found to be 0.40 (A $\mathrm{ndrzejewski}$ et al., 1967), and for Apodemus flavicollis ( $\mathrm{Mel} \mathrm{ch}$ i or, 1834) and Apodemus agrarius (P a lla s, 1771) 0.32 and 0.38 , respectively (A ndrzejew $\mathrm{sk} \mathrm{i,} \mathrm{1968).} \mathrm{The} \mathrm{low} \mathrm{trappability} \mathrm{of} M$. arvalis in comparison with other rodents arises probably from the fact that the traps are not very attractive to this species ( $\mathrm{Trojan} \mathrm{\&} \mathrm{Wojciechow} \mathrm{ska,1967).} \mathrm{It} \mathrm{is} \mathrm{also}$ possible that the oats is a poor bait since the animals have abundance of food in the field.

In the described population of voles no relationship was found between 
the trappability of individuals and their age in distinction to analogous investigations with the population of C. glareolus (G l i w i c z, 1970). The lack of such relationship in the common vole may be caused by the fact that in consecutive series of trappings the interest of individuals in penetrating traps decreases, while in C. glareolus this interest remains on

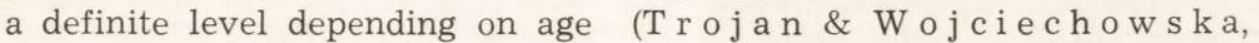
1967; Gliwicz, 1970). A rather low accuracy of separation of age groups in a given population, as based on the time of the first capture, may represents another explanation of this phenomenon.

On the other hand, the relationship between the dynamics of trappability and phenological changes is clearly marked. It depends on the fact that the values of trappability in the individuals belonging to different groups are very similar in the same months of the year (Fig. 1).

Higher trappability of individuals in spring and summer than in autumn and winter was probably caused by seasonal changes in their activity, and not by change in the attractivity of the bait, since abundance of food in summer should decrease the attractivity of the bait, and a dense plant cover in that season should decrease the utilization of traps as a shelter.

It is possible that the increase in the activity of individuals and increase in their trappability in spring and summer is caused by the occurrence of the breeding season. In the autumn-winter season, when reproduction ceases and activity of individuals decreases, also the trappability on individuals of all groups living then in the population is low, independently of the date of the first trapping of a given individual. A similar rule was observed by Gliwicz, (1970) in the population of C. ylareolus.

A difference in the trappability of males and females, particularly distinct during the breeding season, i.e., in the spring-summer period, also disappears in the autumn-winter season. This may be caused by the fact that males intensively penetrate their home range during the whole reproduction season, and that this range includes terrains inhabited by several females (K a r a s heva, 1955). For this reason males have a higher chance of being trapped into a larger number of traps, and in connection with an intense penetration of the home range males can reach in the breeding season a higher trappability than females. Similar differences in the trappability of males and females were observed by Kikkawa (1964) and Gliwicz (1970) in the population of C. glareolus.

A particularly large difference in the trappability of individuals depending on their sex occurs in spring, from February till April, and is caused probably by the earlier achievement of sexual maturity by 
males. This was confirmed by finding some males showing body weight in the range of $31-40 \mathrm{~g}$, hence the heaviest in the population, as early as in February 1971. Females of that weight were found only in April, and since this range of body weight is reached by them during pregnancy lasting 18 to 20 days, it can be assumed that they achieved sexual maturity in March. From this month onwards their trappability increased at a faster rate.

Acknowledgements: The author is grateful to Dr R. Andrzejewski for critical advice concerning the manuscript. Sincere thanks are also due to Dr. K. Andrzejewska and Dr. T. Wierzbowska for help in analysing the materials for this study.

\section{REFERENCES}

1. Andrzejewski R., 1963: Process of incoming, settlement and disapearance of individuals and variations in the numbers of small rodents. Acta theriol., 7, 11: $169-213$.

2. Andrzejewski R., 1969: Analiza wyników połowów drobnych ssaków metodą "Kalendarza złowień«. Zesz. Nauk. 2: 1-104. Warszawa.

3. Andrzejewski R. \& Dominas H., 1964: Niektóre problemy intensyfikacji metodyki ekologicznej. Ekol. pol. B, 9: 291-298.

4. Andrzejewski R., Petrusewicz K. \& Walkowa W., 1959: Preliminary report of results obtained with a living trap in a confined population of mice. Bull. Acad. pol. Sci. II, 7, 9: 367-370.

5. Andrzejewski R., Petrusewicz K. \& Waszkiewicz-Gliwicz J., 1967: The trappability of Clethrionomys glareolus (Schreber, 1780) and other ecological parameters obtained by CMR capture method. Ekol. pol. A. 15, 35: $709-725$,

6. Gliwicz J., 1970: Relation between trappability and age of individuals in a population of the bank vole. Acta theriol., 15, 2: 15-23.

7. K a r a sheva E. B., 1955: Mečenie naziemnych mlekopitajuščih v SSSR. Biul. MOIP, Biol. 60, 5: 31-42.

8. Kikkawa K., 1964: Movement activity and distribution $\mathrm{Cl}$. glareolus and A. sylvaticus in woodland. J. Anim. Ecol., 33: 259-299.

9. Olszewski J. L., 1968: Role of uprooted trees in the movements of rodents in forests. Oikos, 19: 99-104.

10. Petrusewicz K. \& Andrzejewski R., 1962: Natural history of a freeliving population of house mice (Mus musculus L.) with particular references of gruping within the population. Ekol. pol. A, 10, 5: 85-122.

11. Trojan P. \& Wojciechowska B., 1967: The reaction of small rodents to a new object and estimate of population numbers. Ekol. pol. A, 15: 727-736.

Accepted, January 16, 1975

Institute of Ecology,

Polish Academy of Sciences,

Dziekanów Leśny, 05-150 Łomianki 


\section{Hanna GRUNWALD}

\section{DYNAMIKA EOWNOŚCI NORNIKA ZWYCZAJNEGO}

\section{Streszczenie}

Dynamikę łowności nornika zwyczajnego, Microtus arvalis (P a llas, 1778) badano na izolowanym, jednohektarowym polu lucerny. Dane zbierano metodą łowienia, znakowania i wypuszczania osobników. Do połowów używano pułapek żywołownych ustawionych przy koloniach norników. Przynętą w pułapkach był owies. Łowność realną obliczano ze stosunku liczby złowień zrealizowanych $w$ okresie trwania doświadczenia, do liczby wszystkich złowień możliwych $\mathrm{w}$ doświadczeniu. Uzyskano 12908 złowień zrealizowanych przez 1555 osobników w ciągu 316 ekspoz.ycji pułapek. Obliczono łowność realną osobników całej badanej populacji oraz grup osobników wyróżnionych pod względem wieku, ciężaru ciała i płci.

Analizując zmiany lowności osobników poszczególnych grup wiekowych stwierdzono brak prawidłowych zmian łowności osobników zależnych od ich wieku, natomiast łowność osobników różnych grup wiekowych w kolejnych miesiącach roku była na ogół zbliżona (Fig. 1). Wykazano, że samce osiągały łowność wyższą niż samice, przy czym różnice były szczególnie duże w okresach ogólnej wysokiej łowności, natomiast wówczas gdy łowność osobników całej populacji malała zmniejszały się też różnice między płciami (Fig. 2). Ogólny charakter zmian łowności osobników obu płci w cyklu rocznym był taki sam.

$\mathrm{Z}$ powyższych spostrzeżeń wyciągniẹto wniosek, że dynamika lowności $M$. arvalis kształtowana jest przez aktywność osobników, zmieniającą się wraz z fenologią i sezonowością rozrodu. Przeciętna łowność osobników badanej populacji była niska i wynosiła 0,20 . 